\title{
Mitigation Strategies for Cold Stress for Enhancing Livestock Productivity in Temperate Areas of Himachal Pradesh
}

\author{
Anjali Somal ${ }^{1 *}$, Geetanjali Singh ${ }^{1}$, Parul Shukla ${ }^{2}$ and Mukesh Kumar \\ Thakur $^{3}$ \\ ${ }^{1}$ Veterinary Physiology and Biochemistry, Himachal Pradesh, India \\ ${ }^{2}$ Veterinary Anatomy, DGCN COVAS, Palampur, Himachal Pradesh, India \\ ${ }^{3}$ Animal Husbandry Department, Himachal Pradesh, India \\ *Corresponding Author: Anjali Somal, Veterinary Physiology and Biochemistry, \\ Himachal Pradesh, India.
}

Received: December 23, 2021

Published: January 31, 2022

(C) All rights are reserved by Anjali Somal., et al.

\begin{abstract}
Himachal Pradesh is a North-western hill state of India having four major agro-climatic zones with different climatic conditions. The animals reared in different zones experience cold stress when the temperature is below the thermo neutral zone. Climate change studies highlight the increasing temperature and unpredictable weather conditions around the globe. The cold- stress is likely to become more common in the future, in the present scenario of climate change. Across the globe, incidents of intense cold waves vary from region to region. Over India, the cold wave is observed during winter season spanning from December-February. The aim of this review is to give a general outlook of the different climatic factors, their effect on animals as well as adaptation and mitigation strategies for the domestic animals reared in Himachal Pradesh.
\end{abstract}

Keywords: Cold Stress; Temperate Areas; Himachal Pradesh; Mitigation Strategies

\section{Introduction}

Himachal Pradesh a North-western hill state of India lies between $30^{\circ} 22^{\prime}$ to $33^{\circ} 12^{\prime} \mathrm{N}$ latitude and $75^{\circ} 45^{\prime}$ to $79 \circ 04 \mathrm{E}$. The state is divided into four agro climatic zones viz. Shivalik hill zone (Zone-1), Mid hill zone (Zone-2), High hill zone (Zone-3) and Cold dry zone (Zone-4). Area wise zone-4 is the largest with low livestock population density. It is the coldest zone (called as the cold desert) and zone- 1 is the hottest in comparison to the other three zones of Himachal Pradesh. Zone 1 and 2 are highly populous zone comprising of low hills, subtropical and mid hills, humid, respectively. These zones are predominant in cattle and buffalo population. Zone 3 predominately comprises the migratory population of livestock [1,2]. Himachal Pradesh is an agricultural state where agriculture, horticulture, animal husbandry and fisheries activities provide direct employment to about $70-75 \%$ of the total population. However, people living in higher altitudes depend more on livestock because under extreme climate conditions crop production is not possible throughout the year and animal rearing is based on common property resources and forest grazing [1]. The livestock species present in different zones are given in table 1,2.

The body temperature of the livestock species in the agro-ecological zones mentioned above is maintained by the thermoregulatory system within a range of $1^{\circ} \mathrm{C}$ of its normal temperature under ambient conditions that do not impose climatic stress. The range of environmental temperature at which the sensation of heat or cold is absent and the body temperature of animals is maintained with minimal effort is the zone of thermal comfort [3]. This is the most comfortable ambient temperature range with minimal physiological cost and maximum productivity $[4,5]$. Whereas the thermoneutral zone (TNZ) is the range of environmental temperature within which the body temperature is maintained constant with the help 


\begin{tabular}{|c|c|c|c|c|c|c|c|c|}
\hline \multirow{2}{*}{$\begin{array}{l}\text { Agro-ecological } \\
\text { zones }\end{array}$} & \multirow{2}{*}{$\begin{array}{c}\text { Alititude } \\
\text { In meters } \\
\text { above sea } \\
\text { level }\end{array}$} & \multicolumn{4}{|c|}{$\begin{array}{l}\text { THI index Inside shed } \\
\text { Outside shed }\end{array}$} & \multirow{2}{*}{$\begin{array}{l}\text { Agro-ecological } \\
\text { Situation }\end{array}$} & \multirow{2}{*}{$\begin{array}{l}\text { Area coverage } \\
\text { (District wise) }\end{array}$} & \multirow{2}{*}{$\begin{array}{c}\text { Major livestock species } \\
\text { and breed }\end{array}$} \\
\hline & & Max & Min & Max & Min & & & \\
\hline Zone 1 & $350-650$ & 92 & 66 & 92 & 70 & $\begin{array}{l}\text { Subtropical, low } \\
\text { mid hills } \\
\text { (Shivalik hill } \\
\text { zone) } \\
\text { Hot and Humid } \\
\end{array}$ & $\begin{array}{l}\text { Una, Hamirpur, and } \\
\text { Bilaspur and parts } \\
\text { of Sirmaur, Kangra, } \\
\text { Solan and Chamba }\end{array}$ & $\begin{array}{l}\text { Graded, exotic/crossbred } \\
\text { \& hill cattle, graded and } \\
\text { Murrah type buffaloes, } \\
\text { Beetal type goat }\end{array}$ \\
\hline Zone 2 & $651-1800$ & 84 & 48 & 84 & 51 & Mid hills, humid & $\begin{array}{c}\text { parts of Kangra, } \\
\text { Mandi, Solan, } \\
\text { Sirmaur, Kullu, and } \\
\text { Shimla }\end{array}$ & $\begin{array}{l}\text { Graded, exotic/crossbred } \\
\text { \& hill cattle, graded and } \\
\text { Murrah type buffaloes, } \\
\text { Rampur- bushair and } \\
\text { crossbred sheep and } \\
\text { Gaddi goat. }\end{array}$ \\
\hline Zone 3 & $1801-2200$ & 82 & 66 & 89 & 69 & $\begin{array}{l}\text { High hills, wet } \\
\text { temperate }\end{array}$ & $\begin{array}{c}\text { Shimla, Parts of } \\
\text { Chamba, Kullu, } \\
\text { Solan, Mandi and } \\
\text { Kangra }\end{array}$ & $\begin{array}{l}\text { Hill cattle, Rampur- bus- } \\
\text { hair and crossbred sheep } \\
\text { and gaddi goat. }\end{array}$ \\
\hline Zone 4 & $>2200$ & 78 & 56 & 75 & 58 & $\begin{array}{l}\text { High hills and } \\
\text { Dry tempelate } \\
\text { (Cold dry zone) }\end{array}$ & $\begin{array}{l}\text { Kinnaur, Lahaul } \\
\text { Spiti, and parts of } \\
\text { Chamba district }\end{array}$ & $\begin{array}{c}\text { Yak, Chamurthi/Spiti } \\
\text { horses, Chegu goats, } \\
\text { Biangi sheep, Gaddi sheep } \\
\text { and goats }\end{array}$ \\
\hline
\end{tabular}

Table 1: Agro-ecological divisions of Himachal Pradesh and distribution of livestock species [1,2].

\begin{tabular}{|c|c|c|c|}
\hline S. No. & Particulars & Changes in animals during Cold & Mitigation strategies \\
\hline 1. & Behavioral & Huddling in animals [3] & $\begin{array}{l}\text { Cover the animals especially smaller ruminants } \\
\text { during cold days } \\
\text { Cover the animal habitat from all sides during the } \\
\text { night to avoid direct exposure of animals to cold } \\
\text { winds } \\
\text { Use some bedding materials such as dry straw } \\
\text { under animals during winters. }\end{array}$ \\
\hline 2. & Physiological & $\begin{array}{l}\text { Piloerection in animals (hair coat insulation), } \\
\text { shivering and non-shivering (body brown fat) } \\
\text { thermogenesis [3], decreased rectal tempera- } \\
\text { ture and respiration rate, higher } \mathrm{T}_{3} \text { and } \mathrm{T}_{4} \\
\text { blood concentration, high glucose levels [15]. }\end{array}$ & $\begin{array}{c}\text { Construct of climate-smart sheds that allow maxi- } \\
\text { mum sunlight during winters and low radiation } \\
\text { during summers. }\end{array}$ \\
\hline 3. & Nutritional & $\begin{array}{l}\text { Increase in feed intake [25], decrease in } \\
\text { water intake [20] }\end{array}$ & $\begin{array}{l}\text { Use of high-quality forage or pastures } \\
\text { Fat supplementation in ration } \\
\text { Adlib warm water }\end{array}$ \\
\hline 4. & Production & $\begin{array}{l}\text { Decrease in milk production, increase in body } \\
\text { wool, hair and fleece [26]. }\end{array}$ & $\begin{array}{l}\text { Selecting animal breeds especially fit for cold } \\
\text { weather conditions } \\
\text { Improving livestock feeding practice and dietary } \\
\text { additives }\end{array}$ \\
\hline
\end{tabular}

Table 2: Stress Indicators of cold stress and mitigation strategies. 
of behavioral and physiological mechanisms [3]. This range is bounded by the lower critical temperature (LCT) and upper critical temperature (UCT) given in figure 1 for different species. The atmospheric temperature above or below TNZ leads to thermal stress that impairs metabolism, health status, production, reproduction and immune response in mammals [6,7]. This thermal stress is becoming more common in the present situation due to climate change including extreme climatic events [8]. The TNZ range (from LCT to UCT) normally is affected by animal species, breed, age, feed intake, production, housing conditions, the previous state of temperature acclimation or acclimatization (tissue insulation [fat, skin, wool], external insulation (coat) and animal behavior) [6].

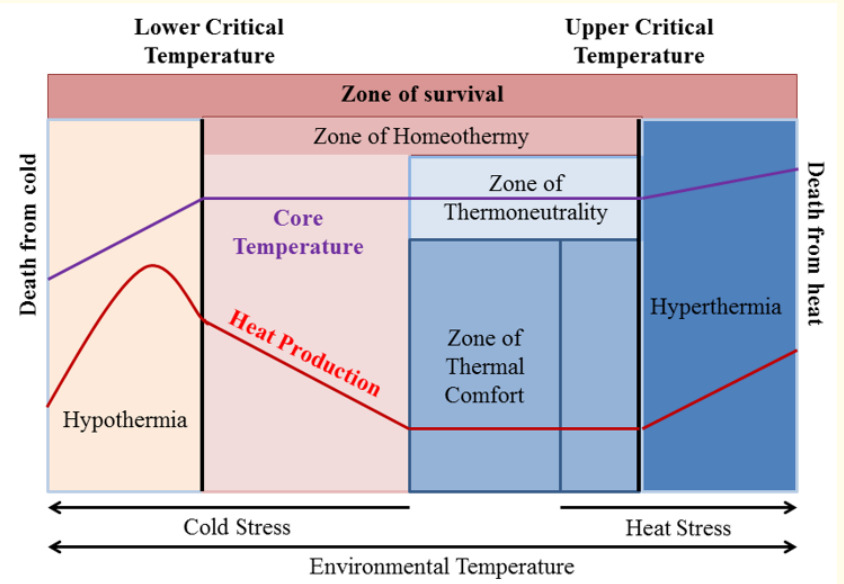

Figure 1: A modified diagram from [3,38]; depicting critical environmental temperatures and zones.

Climate change studies normally highlight the increasing temperature around the globe. However, some regions in the world experience high ambient temperatures (above UCT) during the summer and very low temperatures (below LCT) during the winter [9]. Also, the incidents of intense cold waves vary from region to region, across the globe. In India, the trend of the cold wave has been observed during the winter season (December-February). The cold wave is an extreme weather event occurring during the winter season with a rapid fall in temperature within 24 hours, when the minimum temperature of a place is $10^{\circ} \mathrm{C}$ or less for plains and $0^{\circ} \mathrm{C}$ or less for hilly regions like Himachal Pradesh. The cold weather however is a well-defined and prolonged period of lower temperatures. The cold wave is distinguished by a marked cooling of the air, or the invasion of very cold air, over a large area [10]. During the cold wave, the ambient temperature moves below the LCT and the animal experiences cold stress. The LCT is the temperature at which the animal begins to "feel cold" and must increase heat production to stay warm. It is also the point at which performance begins to decline with the declining temperature [11]. Recently, occurrences of extremely low temperatures along with the storm of dry cold winds from the north into the sub-continent area have been significant in creating cold wave spells. If heavy and persistent snow occurs along with the cold wave, grazing becomes difficult for animals, hence more fodder needs to be provided indoors. Similarly, wildlife also experiences challenges during winter for both shelter and food [10]. Below the LCT, animal metabolism must increase to generate heat to maintain core temperature, or else animals may move to hypothermia, and eventually, death may occur. In the next section of the review, we will focus on the effects of cold stress in animals and the strategies to mitigate the effect of cold stress for optimal production in animals.

\section{Assessment of cold stress in animals}

Cold stress is quantified by means of the wind chill index (WCI) which is an adapted formula (given below) used in the cold stress research in cattle [12].

$\mathrm{WCI}=13.12+0.62 \times \mathrm{T}-13.17 \times[\text { W.S. }]^{0.16}+.40 \times \mathrm{T} \times[\text { W.S. }]^{0.16}$

WCI values are usually expressed in degrees Celsius or Fahrenheit, $\mathrm{T}=$ air temperature $\mathrm{in}^{\circ} \mathrm{C}$, and $\mathrm{WS}$ is the wind speed in $\mathrm{km} / \mathrm{h}$. To the best of our knowledge no scientifically validated cold stress risk classes in terms of WCI have been developed for the dairy animals. The data can only be compared to the established LCTs for the dairy animal to get a rough idea of the potential impact on comfort and physiology. More recently WCI has been criticized for not considering all the climatic parameters that influence thermal comfort [13]. Recent climatic indices like the comprehensive climate index (CCI), incorporate the effects of temperature, humidity, wind-speed and solar radiation in order to improve the assessment of cold or heat stress risk [14].

Effects of Cold stress on general physiology and productivity of animals

The cold stress driven alterations in the vital functions affect the growth, reproduction and adaptive performance of the animal [15]. Immediate decrease in the environmental temperature 
causes decreased respiration rate, which is due to acclimation to cold temperatures so that the animal may decrease evaporative heat loss through the respiratory tract [16]. Consequently, as the water evaporation declines, there is a reduced need for water consumption. There is also a concomitant decrease in rectal temperature. The levels of hemoglobin concentration ( $\mathrm{Hb}$ ), packet cell volume (PCV), total erythrocyte counts (TEC) and total leucocyte count (TLC) are higher during winter and lower during summer [16-20]. It has also been observed that the levels of Hb, PCV and TEC are higher in breeds adaptated to cold hilly climate due to low level of oxygen concentration and higher $\mathrm{Hb}$ and TEC counts help to meet up the oxygen requirement in the body [16,21,22]. Cold environment also stimulates the secretion of thyroid hormone namely $\mathrm{T}_{3}$ and $\mathrm{T}_{4}$ to increase BMR (basal metabolic rate) and heat production for maintaining body temperature. The higher $\mathrm{T}_{3}$ and $\mathrm{T}_{4}$ are accompanied with high blood glucose level [23]. The cold stress leads to activation of hypothalmo-pituitary adrenal axis and cause release of the glucocorticoids [24] but cold adapted animals have suppression of adrenal functions [16].

Prolonged exposure to the mild cold conditions leads to physiological adaptation in animals i.e., increased thermal insulation, higher appetite and basal metabolic intensity, as well as alterations in digestive functions. When animals are exposed to extreme cold stress, substantial dietary energy gets diverted from production towards the generation of body heat $[20,25]$. The average milk yield decreases as the temperature's declines. There is also increase in feed intake, blood glucose levels, free fatty acids, aspartate aminotransferase (AST), albumin levels [19,26]. The milk produced during the cold environment has higher fat, protein, and lactose contents [20]. The reduced productivity observed in ruminants during the colder period of the year is due to these adaptive changes [25]. Furthermore, the decreased milk yield is also related to decreased prolactin secretion. Studies report that animals exposed to cold temperatures have reduced concentrations of prolactin and growth hormones in the blood which are important for lactation $[27,28]$.

\section{Molecular response in animals to the cold stress}

At molecular level the expression level HSP27 is found to increase in both heat and cold stress conditions. Hence, HSP27 can be considered as useful indicator for assessing in vitro stress response which may further be validated in vivo studies [29]. However, HSP70 gene is more closely related to the cold tolerance in animals. A study by Banerjee., et al. [30] demonstrates the HSP70 gene expression is species and breed specific even though HSP70 genes are highly conserved across evolutionary lines. The speciesspecific differences in HSP70 isoforms are most likely due to variations in thermal tolerance [31,32]. Hence HSP70 gene expression can be used as a marker for thermal adaptation in different species

\section{Existing housing management}

The housing of animals in the state is either part of residence or a separate building having east to west orientation to utilize maximum sunshine hours. Due to easy availability, slates are predominantly used as roofing material followed by galvanized iron sheets. The walls are constructed with bricks and stones. The ventilation in these housing is limited. The floors are generally muddy (nonplasterd) and slippery without provision of drainage. The feed is generally provided in manger and watering is done through bucket using tap water [1].

\section{Management and mitigation strategies for cold stress}

Keeping in view environmental conditions and the already existing housing practices followed in Himachal Pradesh following mitigations strategies may be recommended.

\section{Man-made shelter}

In conditions with low wind speed and fewer rains, in forest paddocks (vegetation served as a windbreak), cattle can be housed outside year-round having access to rain shelter, windbreaks and lying places with dry bedding, without severe negative effects on productivity, health or welfare [8]. However, in moderate winter conditions where the minimum and the maximum wind chill is -3.9 and $-9.9{ }^{\circ} \mathrm{C}$ respectively, shelter augmentation significantly improves animal welfare. The wind reduces the effective temperature and increases cold stress on animals hence, providing shelter in the paddocks under moderate winter conditions improves growth [33]. The walls may be constructed with ordinary building bricks having mud plastering on the outer surface on the outer surface. Double-wall construction with 3 to 4 inches of space in between the two walls to provide insulation is recommended. Slanting roof with GI/ asbestos sheet as roofing material along with ceiling is recommended. The height of the roof may be 8 feet on the front side and 12 feet on the rear side for larger animals [1]. Since zone 3 of Himachal Pradesh has semi-pastoral rearing of animals low-cost shelters are to be constructed. 
The roof of an artificial shelter protects against rainfall. The walls can be added and placed perpendicular to the direction of prevailing winds. Shelters are preferably located somewhat higher-never lower-than the surrounding terrain, to prevent water from flowing towards the shelter and accumulating inside. Sufficient individual space and ventilation are important to ensure a dry floor surface [8]. The floor may not be plastered but should be with dry bedding of waste grasses which should be replaced as per need [1]. Cattle are also sensitive to rapid movements [34] so the constructions with cloths or plastic waving in the wind might scare them and hence should be avoided.

\section{Animal feeding}

The environmental temperature should be monitored and additional feed should be offered to the animal in cold weather to meet the increased metabolic demands of the animal. If wet feeds are fed, make sure they are not frozen [35]. Increased energy content (77\% vs. $70-72 \%$ TDN) and protein (17.5\% vs. $14.5 \% \mathrm{CP}$ ) must be provided to animals [36]. The combination of salt and fat can be added to the diet as it has been reported to elevate body temperature and may benefit animals in winters [37]. The rations constituting about $20 \%$ as compared to $17 \%$ fiber are helpful to increase fat percentage in milk and reduce the effects of cold temperatures in animals. The outdoor animals require about 15 to $20 \%$ more feed for the winter season than animals kept in confinement housing. Provision of hay, silage, feed blocks, and urea molasses supplementations may be done during the fodder shortage period [36].

\section{Water supply}

Cows should have ample water available at all times preferably warm as frozen troughs and excessively cold water seriously limits water intake in animals. Tank heaters can be used to prevent water sources from freezing [36]. Limited water intake also limits the feed intake and makes it more difficult for dairy animals to meet their energy requirements [34].

\section{Animal rearing}

Dry teats after the dairy animal leaves the milking parlor are important to reduce cold stress. It can be done by dipping the teats for about 30 seconds and then blot drying using a paper towel. Wet coats have reduced insulating properties and make cows more susceptible to cold stress hence it's important to keep the cows clean and dry [34]. Calf jackets and blankets made of local gunny bags may be used to keep the calves warm. With planning calving season may be shifted to too late in spring/ early summer, preventing cows to spend late lactation in cold months [36].

\section{Genetic selection of breeds}

The lower magnitude of changes occurs in breeds' adapted to cold during winter and hence these animals are resistant to coldinduced hypothermia [16,22]. Recent techniques like infrared thermography are being used to evaluate response of animals to environment and differentiate in between different groups [39]. Modern advances like genome sequencing and transcription profiling can help to display the genetic basis of adaptation to climate change. Hence, thorough studies are needed to understand the ecological context of the environmental changes with genetic regulation in animals [40].

\section{The way forward}

Despite the enormous importance of livestock in hilly areas, very little research work has been undertaken to date on the interaction of climate and increasing climate variability on the productivity performance of different livestock species. Hence, more research work needs to be taken up to enhance the sustainability of hill livestock production systems under changing climate scenarios, mitigation strategies for sustaining livestock-based livelihood in cold winter seasons.

\section{Bibliography}

1. Kumar Ravinder., et al. "Impact of climate change on cattle Production and mitigation strategies in Himachal Pradesh". Department of Veterinary Physiology and Biochemistry, DGCN COVAS CSKHPKV, Palampur (2012).

2. Kapri A and Raj S. "Role of Extension Services in Adaptation to Climate Change in Himachal Pradesh". Discussion Paper 12, MANAGE- Centre for Agricultural Extension Innovations, Reforms and Agripreneurship, National Institute for Agricultural Extension Management (MANAGE), Hyderabad, India (2020).

3. Hafez Elsayed Saad Eldin. "Adaptation of domestic animals". Adaptation of domestic animals. (1968).

4. McDowell and Robert E. "Improvement of livestock production in warm climates". Improvement of Livestock production in warm climates (1972).

5. Folk G Edgar. “Textbook of environmental physiology” (1974). 
6. Yousef MK. "Stress physiology in livestock". Volume I. Basic principles. CRC Press (1985).

7. Nardone Alessandro., et al. "Effects of climate changes on animal production and sustainability of livestock systems". Livestock Science 130.1-3 (2010): 57-69.

8. Moons Christel Palmyre Henri., et al. "Importance of outdoor shelter for cattle in temperate climates". Livestock Science 159 (2014): 87-101.

9. Villalba Juan J. "Animal Welfare in Extensive Production Systems". 5m Books Ltd, 2016.

10. National Webinar on Cold Wave Risk Reduction (2021).

11. Wagner Donald G. "Effects of cold stress on cattle performance and management factors to reduce cold stress and improve performance". The Bovine Practitioner (1988): 88-93.

12. Tucker Cassandra B., et al. "Effects of shelter and body condition on the behaviour and physiology of dairy cattle in winter". Applied Animal Behaviour Science 105.1-3 (2007): 1-13.

13. Hahn GL., et al. "Perspective on development of thermal indices for animal studies and management". EAAP Technical Services 7 (2003): 31-44.

14. Mader Terry L., et al. "A comprehensive index for assessing environmental stress in animals". Journal of Animal Science 88.6 (2010): 2153-2165.

15. Sejian Veerasamy., et al. "Physiological rhythmicity in Malpura ewes to adapt to cold stress in a semi-arid tropical environment". Biological Rhythm Research 49.2 (2018): 215-225.

16. Banerjee Dipak., et al. "Seasonal variations in physio-biochemical profiles of Indian goats in the paradigm of hot and cold climate". Biological Rhythm Research 46.2 (2015): 221-236.

17. Upadhyay RC and MVN Rao. "Haematological and biochemical constituents of blood in goats upto the one-year age". Indian Journal of Dairy Science (1985).

18. Abdelatif Abdalla M., et al. "Seasonal variation in erythrocytic and leukocytic indices and serum proteins of female Nubian goats". Middle-East Journal of Scientific Research 4.3 (2009): 168-174.

19. Berian Sindhu., et al. "Effect of Cold Stress on Milk Yield, Physiological and Hemato-biochemical Profile of Cross Bred Dairy Cattle". Journal of Animal Research 9.2 (2019): 335-338.
20. Coloma-García Wellington., et al. "Effects of Cold Exposure on Some Physiological, Productive, and Metabolic Variables in Lactating Dairy Goats". Animals 10.12 (2020): 2383.

21. Webster AJF. “Adaptation to cold. In: Robertshaw D, editor. Environmental physiology. Physiology series I. Baltimore, MD: University Park Press (1974): 7.

22. Slee J. "Physiological responses and adaptations of sheep". Stress Physiology in Livestock. Volume II. Ungulates (1985): 111-127.

23. Campanile G., et al. "Metabolic profile in ltalian Mediterranean Buffaloes". Proc. Fourth World Buffalo Congress, Sao Paolo, Brazil (1994).

24. Bhimte A., et al. "Endocrine changes in livestock during heat and cold stress". Journal of Pharmacognosy and Phytochemistry 7.4 (2018): 127-132.

25. Young BA. "Ruminant cold stress: Effect on production". Journal of Animal Science 57.6 (1983): 1601-1607.

26. Brouček J., et al. "Estimation of cold stress effect on dairy cows". International Journal of Biometeorology 35.1 (1991): 29-32.

27. Tucker H., et al. "Effects of ambient temperature and relative humidity on serum prolactin and growth hormone in heifers". Proceedings of the Society for Experimental Biology and Medicine 151.3 (1976): 623-626.

28. GL Mader., et al. "Perspective on development of thermal indices for animal studies and management". EAAP Technical Service 7 (2003): 31-44.

29. Hart IC. "Effect of 2-bromo- $\alpha$-ergocryptine on milk yield and the level of prolactin and growth hormone in the blood of the goat at milking". Journal of Endocrinology 57.1 (1973): 179180.

30. Mohanarao G., et al. "HSP70 family genes and HSP27 expression in response to heat and cold stress in vitro in peripheral blood mononuclear cells of goat (Capra hircus)". Small Ruminant Research 116.2-3 (2014): 94-99.

31. Banerjee Dipak., et al. "Seasonal variation in expression pattern of genes under HSP70". Cell Stress and Chaperones 19.3 (2014): 401-408. 
32. Yamashita Michiaki Kazunori Hirayoshi and Kazuhiro Nagata. "Characterization of multiple members of the HSP70 family in platy fish culture cells: molecular evolution of stress protein HSP70 in vertebrates". Gene 336.2 (2004): 207-218.

33. Hightower Lawrence E., et al. "Heat shock responses of closely related species of tropical and desert fish". American Zoologist 39.6 (1999): 877-888.

34. Holmes CW., et al. "Effects of winter weather on the growth rate and heat production of dairy cattle". New Zealand Journal of Agricultural Research 21.4 (1978): 549-556.

35. Grandin Temple. "Principles for low stress cattle handling" (1999).

36. Rai Chandan Kumar., et al. "Climate change: Impact on dairy animals vis-à-vis adaptation strategies followed by dairy farmers". Journal of Pharmacognosy and Phytochemistry 7.2 (2018): 2842-2846.

37. Manzoor A., et al. "Mitigating winter vagaries in dairy animals: A review". International Journal of Veterinary Sciences and Animal Husbandry 4.1 (2019): 01-05.

38. Gaughan JB and Terry L Mader. "Effects of sodium chloride and fat supplementation on finishing steers exposed to hot and cold conditions". Journal of Animal Science 87.2 (2009): 612621.

39. Lallo, Cicero HO, et al. "The impact of climate change on small ruminant performance in Caribbean communities". Environmental Sustainability and Climate Change Adaptation Strategies. IGI Global (2017): 296-321.

\section{Assets from publication with us}

- Prompt Acknowledgement after receiving the article

- Thorough Double blinded peer review

- Rapid Publication

- Issue of Publication Certificate

- High visibility of your Published work

Website: www.actascientific.com/

Submit Article: www.actascientific.com/submission.php

Email us: editor@actascientific.com

Contact us: +919182824667

Citation: Anjali Somal., et al. "Mitigation Strategies for Cold Stress for Enhancing Livestock Productivity in Temperate Areas of Himachal Pradesh". Acta Scientific Veterinary Sciences 4.2 (2022): 81-87. 